\section{Healy ready to take on NIH}

\section{Washington}

AFTER more than a year and a half of anxious anticipation, the US National Institutes of Health (NIH) are finally to get a leader. On 14 March, cardiologist Bernadine P. Healy, President George Bush's nominee for the NIH directorship, sailed through confirmation hearings before a Senate committee chaired by Edward M. Kennedy. Final approval of the full Senate is considered certain, which means that Healy may actually take office within the next few weeks.

Described by those who have worked with her as "smart", "very traditional", "strongwilled" and a "tough bird", Healy seemed eager to take on the challenge of guiding the NIH through what biomedical scientists argue are unusually hard times. She revealed something about what she thinks most important through what she chose to talk about in her testimony and responses during two hours of harmonious give and take. After months of prudent silence, the confirmation hearing marked Healy's first public comments on her views about the scientific enterprise.

Calling the NIH "a national treasure", Healy nonetheless made a point of telling the Senate committee that she does not think researchers have an entitlement to federal funding just because large numbers of them want support. Rather, she said, the United States has an obligation to fund NIH researchers at the home campus in Bethesda, Maryland, and at more than 1,700 institutions around the country and around the world, "not because they are entitled to it or because they always behave so well, but because it is the only way to fulfill our goals for a healthier world".

Healy, who is 47 , is a graduate of Vassar College and Harvard Medical School, and trained at Johns Hopkins University, where she rose to the rank of professor of medicine. She spent nearly two years in the White House Office of Science and Technology Policy during Ronald Reagan's presidency, and comes to NIH from her current post as head of the Research Institute of the Cleveland Clinic Foundation.

The delay in finding a successor to former NIH director James B. Wyngaarden, who left the institutes in 1989, is connected to the role abortion plays at all levels of US politics. The Bush administration was under considerable pressure to appoint someone who is vocally opposed not only to abortion but also to the use of human fetal tissue in transplantation research. At least a couple of candidates rejected the job, or were rejected, over that issue.

Indeed, Healy's own nomination has come under attack because as a member of a presidentially appointed NIH study panel, she voted with the majority to allow fetal tissue research under certain carefully prescribed circumstances.
In the end, the matter was settled with a political compromise that one senator described this way: Healy will "make medical decisions free of political concerns", and will leave "policy to politicians". Although her written testimony before the Senate contained no mention of fetal research, she volunteered as an aside that she will support the administration's long-standing ban on these studies.

Saying that sometimes science needs to take "time out" when its goals collide with the moral and ethical concerns of the society, Healy cited a number of areas in which science has had to be accommodating - recombinant DNA research, animal research and the human genome project among them. The experienced politician in Healy said that "science indeed does not live by and unto itself alone".

Thus. in the vein of responding to public

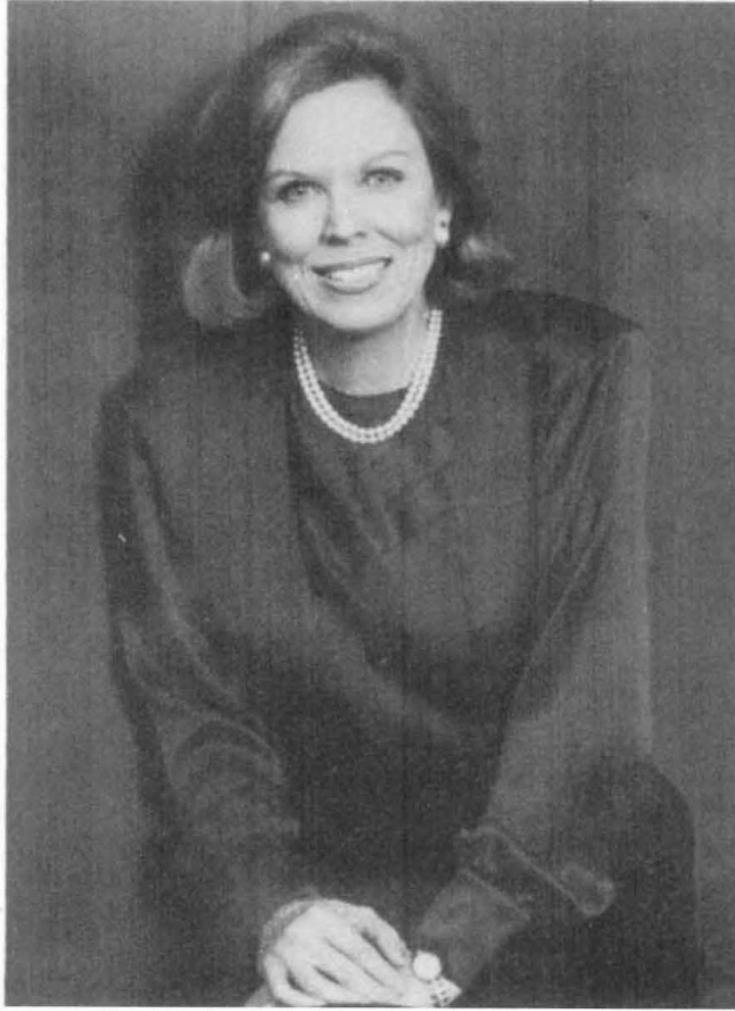

Bernadine Healy wants to protect the Mozarts in modern day science.

concern, Healy found herself in the convenient position of being able to endorse the politically popular idea that women's health deserves more attention from NIH. In response to a query from Maryland Senator Barbara Mikulski, Healy, long concerned about heart disease in women, said women's health generally is "one of my most favorite subjects". As the first NIH director to have a \$20 million discretionary fund, Healy said that she has already decided to allocate $\$ 2-\$ 3$ million of that money to the institutes' new office of women's health.

Tackling the crisis mentality that has arisen because NIH cannot fund more than
24 per cent of the deserving grants they review - a percentage Healy called "way too low" - she made plain her willingness to tackle what NIH call "cost management", but which is known to researchers as a system for cutting 10 per cent or more from their grants. NIH officials have been working on a plan to bring grant costs under control without approaching the touchy issue of indirect costs or overhead that is paid to universities to support such items as administration and libraries. It has become a matter of particular concern recently and the subject of congressional hearings (see page 182).

NIH cost planners, working without the leadership of a full-time director, told Healy they would not touch that politically sensitive issue. "Well, Senator", she declared, "I'm prepared to touch it." Nearly $\$ 2,000$ million of NIH's $\$ 8,000$ million annual budget goes to indirect costs which currently are now outside NIH's control. Indirect cost rates are now negotiated between the university and a federal auditor unconnected to $\mathrm{NIH}$, who operates according to rules written by the White House Office of Management and $\mathrm{Bu}-$ dget (OMB). Healy wants to see $\mathrm{NIH}$ included in that negotiating process or in any revision of the OMB rules.

Technology transfer is another topic high on the new director's agenda. A strong advocate of collaboration among basic scientists, physicians, and industry, she favours the US push, under a 1986 law, actively to foster such research, despite instances of real or perceived conflict of interest that may arise as complex collaborative agreements are negotiated. "Those difficulties are not a reason to walk away from a principle of great social value", she said. While she sees the need for some flexibility in basic research agreements, she draws a stricter line when it comes to clinical medicine.

Having first-hand experience with conflict of interest over stock she once owned in Genentech, she has taken the lead in declaring that physicians should have no financial ties to companies whose drugs or devices they are testing in patients.

Healy also chose to speak to the Senate rather poetically about scientific creativity. "There is a lesson for science in the play Amadeus", she offered. Mozart the creative genius, "magical and brilliant", was also "difficult, childish, nasty, and unconventional". On the other hand, his rival Salieri was "talented in a workmanlike way and popular at court". Said Healy, "If medicine is to succeed, the Mozarts must be allowed to flourish". She did not say whether she had any particular modern-day Mozart in mind, and no one asked. Barbara J. Culliton 